\title{
ANALISIS KADAR AMILOID BETA PLASMA DENGAN GANGGUAN KOGNITIF PADA DIABETES MELITUS TIPE 2
}

\author{
ANALYSIS OF PLASMA LEVELS OF BETA AMYLOID WITH COGNITIVE \\ IMPAIRMENT IN TYPE 2 DIABETES MELLITUS
}

Yuliarni Syafrita, * Darwin Amir, * Eva Decroli, ** Restu Susanti*

\begin{abstract}
Introduction: Type 2 diabetes mellitus (T2DM) and Alzheimer's disease are two kind of neurodegenerative disease that related with age. Patients with DM show a tendency to develop Alzheimer's disease, but there is no single marker for predicting a DM case will develop into Alzheimer's disease. Amyloid cascade beta disturbance is one factor involved in the pathogenesis of DM disease as well as in Alzheimer's disease, and still believed to be the main factor causing Alzheimer's dementia.
\end{abstract}

Aims: This research was aimed to determine the correlation between beta amyloid plasm level and demographic factors with the occurrence of cognitive dysfunction in type 2 diabetes mellitus patients.

Methods: This was a cross-sectional design study on patients with DM in special DM clinic at M Djamil and Ibnu Sina hospital, Padang, between August-October 2016. Cognitive function was examined using the Montreal Cognitive Assessment Indonesian version (MoCA-Ina). Beta amyloid level was measured by enzyme-linked immunosorbent assay (ELISA) technique. Beta amyloid diagnostic ability was analyzed by using receiver operating characteristics (ROC). The correlation between the variables were analyze by using Chi-square, and $p$ value $p \leq 0.05$ was considered to be significant. To determine the strongest variables which correlated to cognitive dysfunction, logistic regression analysis were performed.

Result: 65 subjects included in this study, where cognititve dysfuntion were present in 35 patients (58.3\%). There were significant correlation between disease duration and low levels of 42 beta amyloid in plasma (AB42) with the occurrence of cognitive dysfunction. The multivariate analysis showed that the disease duration, followed by low levels of A 42 and education level were the variables correlated with cognitive dysfunction.

Discussion: There were a correlation between low levels of 42 beta amyloid in plasma with the occurrence of cognitive dysfunction in type 2 diabetes mellitus patients.

Keywords: Beta amyloid, cognitive impairment, demographic factors, type 2 DM

\section{ABSTRAK}

Pendahuluan: Penyakit diabetes melitus tipe 2 (DM) dan penyakit Alzheimer adalah dua penyakit neurodegeneratif yang sering berhubungan dengan usia. Pasien dengan DM menunjukkan kecenderungan untuk menderita penyakit Alzheimer, namun belum ada satupun penanda untuk memprediksi kasus DM yang akan berkembang menjadi penyakit Alzheimer. Gangguan kaskade amiloid beta merupakan faktor yang terlibat pada patogenesis penyakit DM maupun pada penyakit Alzheimer, dan sampai sekarang masih dipercaya sebagai faktor utama yang menyebabkan demensia Alzheimer.

Tujuan: Mengetahui hubungan kadar amiloid beta plasma dan faktor demografi dengan gangguan fungsi kognitif pada penderita DM.

Metode: Penelitian dengan desain potong lintang ini, terhadap pasien DM yang berobat di Poliklinik khusus diabetes RSUP Dr. M Djamil dan RS Islam Ibnu Sina, Padang, pada periode Agustus-Oktober 2016. Penilaian gangguan kognitif menggunakan Montreal Cognitive Assesment versi Indonesia (MoCA-Ina), dinyatakan terganggu jika nilai $<26$. Kadar amiloid beta diperiksa dengan metode enzyme-linked immunosorbent assay (ELISA) dan kemampuan diagnostik amiloid beta dianalisis dengan receiver operating characteristics (ROC). Hubungan antar variabel diuji dengan Chisquare, dikatakan bermakna bila nilai $\mathrm{p} \leq 0,05$. Dilakukan analisis regresi logistik untuk menentukan variabel yang paling kuat hubungannya dengan gangguan fungsi kognitif.

Hasil: Didapatkan 65 subjek dengan rerata usia 61,62 \pm ,6 tahun dan sebanyak 53,8\% mengalami gangguan fungsi kognitif. Didapatkan hubungan yang bermakna antara lama sakit dan rendahnya kadar A $\beta 42$ plasma dengan terjadinya gangguan kognitif. Pada analisis multivariat diketahui bahwa urutan kekuatan variabel yang berhubungan dengan terjadinya gangguan fungsi kognitif adalah lama sakit, rendahnya kadar A $\beta 42$ plasma, dan tingkat pendidikan.

Diskusi: Terdapat hubungan antara lama sakit dan rendahnya kadar A $\beta 42$ plasma dengan terjadinya gangguan kognitif pada penderita DM.

Kata kunci: Amiloid beta, DM tipe 2, faktor demografi, gangguan kognitif

*Departemen Neurologi FK Universitas Andalas/RSUP Dr. M Djamil, Padang; **Departemen Penyakit Dalam FK Universitas Andalas/ RSUP Dr. M Djamil, Padang. Korespondensi: ysyafrita@yahoo.com. 


\section{PENDAHULUAN}

Beberapa studi epidemiologi telah menunjukan bahwa penderita diabetes melitus (DM) berisiko mengalami gangguan kognitif dan demensia, yaitu 1,5-2,5 kali lebih tinggi untuk menderita demensia dibandingkan populasi non-DM pada kelompok usia lanjut. ${ }^{1}$ Dilaporkan juga bahwa tingginya kadar gula darah, khususnya gula darah dua jam postprandial, berkorelasi positif dengan kejadian demensia, baik demensia Alzheimer maupun demensia vaskuler. ${ }^{2}$ Mekanisme yang mendasari hubungan antara DM dan demensia masih belum jelas, namun cenderung multifaktorial, yang mencerminkan kompleksnya gangguan metabolik pada DM. Hal ini berhubungan dengan didapatkannya gambaran patologi campuran dari subtipe demensia pada otak penderita demensia yang berkembang dari penderita DM..$^{3-4}$

Beberapa faktor yang berhubungan dengan DM, seperti faktor risiko kardiovaskular, toksisitas glukosa, perubahan sensitivitas insulin yang mengakibatkan resistensi insulin, faktor demografi dan faktor sosial ekonomi (misalnya, usia dan pendidikan), komorbiditas lainnya (misalnya, depresi), dan faktor genetik (misalnya, genotip APOEe4) juga bisa menjadi faktor penentu penting dari peningkatan risiko demensia pada penderita DM. ${ }^{5-6}$

Menumpuknya plak amiloid pada area spesifik di otak, dipercaya sebagai patogenesis awal dari demensia Alzheimer. Amiloid beta $(\mathrm{A} \beta)$ adalah sejenis protein yang dihasilkan dari pemecahan protein transmembran amyloid precursor protein (APP) oleh enzim beta ( $\beta$ ) dan gamma $(\gamma)$ sekretase menjadi $A \beta$ monomer yang larut. Dari pemecahan ini, dihasilkan beberapa jenis $A \beta$ yang terdiri dari 39 sampai 43 asam amino, namun yang terbanyak adalah $A \beta 40$ dan $A \beta 42 .^{7-8}$ Ada dua jenis $A \beta$ yang terpenting pada patologi demensia ini, yaitu $A \beta 40$ dan $A \beta 42$. Dalam keadaan normal, produksi dan pemecahan serta pembersihan $A \beta$ di otak itu berada dalam keseimbangan, namun karena sesuatu hal patologis, terjadilah penumpukan $A \beta$ di otak yang akan mencetuskan rangkaian proses patologi yang mendasari gangguan kognitif. ${ }^{7}$

Penumpukan $A \beta$ pada penderita demensia Alzheimer tipe sporadik diduga akibat menurunnya pembersihan $A \beta$ di otak, sehingga jumlah $A \beta$ yang dikeluarkan dari otak ke sistemik melalui cairan serebrospinal (CSS) akan berkurang. Sebagai akibatnya, akan terjadi penumpukan kadar $\mathrm{A} \beta$ di otak dan menyebabkan pengurangan jumlah $A \beta$ di CSS dan plasma. ${ }^{9}$ Hal inilah yang perlu dinilai berdasarkan faktor-faktor lain yang dapat memengaruhinya.

\section{TUJUAN}

Mengetahui hubungan kadar plasma $A \beta$ dan pengaruh faktor usia, jenis kelamin, tingkat pendidikan, keteraturan berobat, dan lama sakit terhadap gangguan fungsi kognitif pada penderita DM tipe 2.

\section{METODE}

Penelitian observasional dengan desain studi potong lintang selama periode Agustus-Oktober 2016 di Poliklinik Khusus Diabetes RSUP Dr. M Djamil dan RS Islam Ibnu Sina, Padang. Subjek adalah penderita DM minimal 5 tahun dan menyatakan bersedia untuk berpartisipasi dalam penelitian ini. Adapun kriteria eksklusi adalah penderita yang sedang/pernah menderita stroke, sindrom Parkinson, epilepsi, tumor otak, infeksi SSP, atau cedera kepala. Pemeriksaan fungsi kognitif menggunakan tes neuropsikologi Montreal Cognitive Assesment versi Indonesia (MoCA-Ina), dinyatakan terganggu jika nilai $<26$. Kadar plasma $\mathrm{A} \beta$ diperiksa dengan teknik enzyme-linked immunosorbent assay (ELISA) di laboratorium Biomedik Fakultas Kedokteran Universitas Andalas.

Semua prosedur pemeriksan pasien dan pengambilan sampel darah telah disetujui oleh Komite Etik Fakultas Kedokteran Universitas Andalas, Padang, dan dilaksanakan sesuai aturan dan prosedur penelitian pada manusia. Kemampuan diagnostik $\mathrm{A} \beta$ dianalisis dengan receiver operating characteristics (ROC). Hubungan antar variabel diuji dengan Chisquare, dikatakan bermakna bila nilai $\mathrm{p} \leq 0,05$. Untuk menentukan variabel yang paling kuat hubungannya dengan gangguan fungsi kognitif dilakukan analisis regresi logistik.

\section{HASIL}

Didapatkan 65 subjek dengan rerata usia $61,62 \pm 7,6$ tahun, proporsi laki-laki hampir sama dengan perempuan $(45 \%$ dan $55 \%)$, dan mayoritas berpendidikan $<12$ tahun $(61,5 \%)$. Rerata subjek 
menderita DM selama 5-40 tahun dan hanya separuh yang berobat teratur (Tabel 1). Sebanyak 53,8\% subjek mengalami gangguan kognitif (MoCa-Ina <26) dengan nilai rerata 11-28.

Tabel 1. Karakteristik Subjek Penelitian $(n=65)$

\begin{tabular}{ll}
\hline Faktor Demografi & $\mathbf{n}(\mathbf{\%})$ \\
\hline Usia (rerata+SD) tahun & $61,62 \pm 7,6$ \\
- $\leq 60$ tahun & $35(53,8)$ \\
- $>60$ tahun & $30(46,2)$ \\
Jenis Kelamin & \\
- Laki-laki & $29(44,6)$ \\
- Perempuan & $36(55,4)$ \\
Pendidikan (median/min-maks) & $12(6-21)$ \\
- $<12$ tahun & $40(61,5)$ \\
- $\geq 12$ tahun & $25(38,5)$ \\
Keteraturan Berobat & \\
- Tidak Teratur & $32(49,2)$ \\
- Teratur & $33(50,8)$ \\
Lama Sakit (median/min-maks) & $9(5-40)$ \\
- $\geq 10$ tahun & $30(46,2)$ \\
- $<10$ tahun & $35(53,8)$ \\
MoCA-Ina (median/min-maks) & $23(11-28)$ \\
- <26 & $35(53,8)$ \\
- $\geq 26$ & $30(46,2)$ \\
\hline
\end{tabular}

SD: standar deviasi; min-maks: minimal-maksimal; MoCA-Ina: Montreal Cognitive Assesment versi Indonesia.

Tabel 2. Distribusi Kadar Aß40 dan Aß42 (n=65)

\begin{tabular}{ll}
\hline \multicolumn{1}{c}{ Kadar } & n (\%) \\
\hline A $\beta 40$ & \\
- Rendah & $38(58,5)$ \\
- Tinggi & $27(41,5)$ \\
A $\mathbf{\beta 4 2}$ & \\
- Rendah & $35(53,9)$ \\
- Tinggi & $30(47,1)$ \\
\hline
\end{tabular}

A $\beta$ : Amiloid beta.

Amiloid beta yang diteliti pada penelitian ini belum mempunyai nilai normal pada populasi. Oleh sebab itu ditentukan titik potong (cut off point) $\mathrm{CoP}$ ) optimal berdasarkan kurva receiver operating characteristic (ROC). Nilai CoP kadar A $\beta 40$ adalah $1759,13 \mathrm{pg} / \mathrm{ml}$, sedangkan nilai CoP kadar $\mathrm{A} \beta 42$ adalah $42,12 \mathrm{pg} / \mathrm{ml}$. Kadar amiloid beta dinyatakan rendah dan tinggi jika berada di bawah atau di atas nilai CoP tersebut. Tabel 2 menunjukkan bahwa sebagian besar subjek memiliki kadar A $\beta 40$ dan A $\beta 42$ yang rendah (58,5\% dan 53,9\%).

Di antara berbagai faktor demografi (Tabel 3), terdapat hubungan yang bermakna antara lama sakit dengan terjadinya gangguan fungsi kognitif $[\mathrm{p}=0,016$; RO:3,5 (1,25-9,83)]. Subjek yang menderita DM >10 tahun akan 3,5 kali berisiko mengalami gangguan kognitif dibandingkan subjek yang menderita $\leq 10$ tahun.

Di antara kedua jenis amiloid beta (Tabel 4), hanya kadar A $\beta 42$ plasma yang berhubungan bermakna dengan gangguan kognitif pada pasien DM [p=0,038; RO:2,88 (1,05-7,89)]. Untuk melihat variabel yang paling berpengaruh dominan terhadap terjadinya gangguan fungsi kognitif, dilakukan analisis multivariat dengan regresi logistik. Didapatkan variabel yang berhubungan dengan terjadinya gangguan fungsi kognitif pada penderita DM secara berturut-turut adalah lama sakit, rendahnya kadar A $\beta 42$, dan rendahnya tingkat pendidikan (Tabel 6).

\section{PEMBAHASAN}

Kejadian gangguan kognitif pada populasi umum maupun pada penderita DM akan bertambah dengan bertambahnya usia. Pada penelitian ini gangguan kognitif lebih banyak ditemukan pada kelompok usia $>60$ tahun dengan risiko 2,21 kali lebih tinggi dibandingkan kelompok $\leq 60$ tahun. Namun secara statistik perbedaannya tidak bermakna, dapat disebabkan oleh variasi usia yang sangat luas, yaitu dari usia 50-84 tahun.

Rawlings dkk menemukan bahwa kondisi prediabetes, kontrol yang tidak teratur, dan lamanya menderita DM berhubungan dengan buruknya fungsi kognitif pada penderita DM. ${ }^{10}$ Penelitian ini juga mendapatkan hubungan yang signifikan antara lamanya menderita diabetes dengan gangguan kognitif. Hubungan langsung lamanya menderita diabetes dengan munculnya gangguan kognitif belum dapat diterangkan, namun diduga berhubungan dengan kontrol gula yang kurang bagus, terutama terjadinya hipoglikemia dan bila diabetes sudah terdiagnosis pada usia pertengahan. ${ }^{10}$

Pada sebagian besar penelitian ditemukan adanya pengaruh tingkat pendidikan terhadap kejadian gangguan kognitif, seperti halnya penelitian ini bahwa subjek dengan pendidikan rendah $(<12$ tahun) berisiko untuk mengalami gangguan kognitif 1,91 kali lebih tinggi dibandingkan tingkat pendidikan yang lebih tinggi. Lenehan dkk menemukan bahwa 
Tabel 3. Hubungan Faktor Demografi dengan Fungsi Kognitif

\begin{tabular}{|c|c|c|c|c|}
\hline \multirow[b]{2}{*}{ Faktor Demografi } & \multicolumn{2}{|c|}{ Fungsi Kognitif } & \multirow[b]{2}{*}{$\mathbf{p}$} & \multirow[b]{2}{*}{ RO } \\
\hline & $\begin{array}{l}\text { Terganggu } \\
\quad(n=35)\end{array}$ & $\begin{array}{c}\text { Normal } \\
(n=30)\end{array}$ & & \\
\hline $\begin{array}{l}\text { Usia } \\
\text { - }>60 \text { tahun } \\
-\quad \leq 60 \text { tahun }\end{array}$ & $\begin{array}{l}22 \\
13\end{array}$ & $\begin{array}{l}13 \\
17\end{array}$ & 0,115 & $2,21(0,82-5,99)$ \\
\hline $\begin{array}{l}\text { Jenis Kelamin } \\
\text { - } \quad \text { Laki-laki } \\
\text { - } \quad \text { Perempuan }\end{array}$ & $\begin{array}{l}17 \\
18\end{array}$ & $\begin{array}{l}12 \\
18\end{array}$ & 0,448 & $1,42(0,53-3,79)$ \\
\hline $\begin{array}{l}\text { Lama Pendidikan } \\
\text { - } \leq 12 \text { tahun } \\
-\quad>12 \text { tahun }\end{array}$ & $\begin{array}{l}24 \\
11\end{array}$ & $\begin{array}{l}16 \\
14\end{array}$ & 0,208 & $1,91(0,69-5,25)$ \\
\hline $\begin{array}{l}\text { Lama Mengidap DM } \\
\text { - } 10 \text { tahun } \\
\text { - } \leq 10 \text { tahun }\end{array}$ & $\begin{array}{l}21 \\
14\end{array}$ & $\begin{array}{c}9 \\
21\end{array}$ & 0,016 & $3,5(1,25-9,83)$ \\
\hline $\begin{array}{l}\text { Keteraturan Berobat } \\
\text { - Tidak teratur } \\
\text { - Teratur }\end{array}$ & $\begin{array}{l}19 \\
16\end{array}$ & $\begin{array}{l}13 \\
17\end{array}$ & 0,379 & $1,55(0,58-4,15$ \\
\hline
\end{tabular}

RO: rasio Odds; DM: diabetes melitus.

Tabel 4. Hubungan Kadar Beta Amiloid dengan Fungsi Kognitif ( $n=65)$

\begin{tabular}{|c|c|c|c|c|}
\hline \multirow{2}{*}{ Variabel } & \multicolumn{2}{|c|}{ Fungsi Kognitif } & \multirow{2}{*}{$\mathbf{p}$} & \multirow{2}{*}{ RO } \\
\hline & Terganggu & Normal & & \\
\hline \multicolumn{5}{|l|}{ Kadar A $\beta 40$} \\
\hline - Tinggi & 16 & 19 & 0,461 & $1,45(0,54-3,94)$ \\
\hline - Rendah & 11 & 19 & & \\
\hline \multicolumn{5}{|l|}{ Kadar A $\beta 42$} \\
\hline - Rendah & 23 & 12 & 0,038 & $2,88(1,05-7,89)$ \\
\hline - Tinggi & 12 & 18 & & \\
\hline
\end{tabular}

Tabel 5. Hubungan Faktor-faktor dengan Terjadinya Gangguan Fungsi Kognitif (n=65)

\begin{tabular}{llccc}
\hline & Variabel & Koefisien & $\mathbf{p}$ & RO (IK 95\%) \\
\hline Langkah 1 & Usia & 0,335 & 0,567 & $1,39(0,45-4,39)$ \\
& Lama sakit & 1,185 & 0,051 & $3,27(0,99-10,76)$ \\
& Tingkat pendidikan & 0,377 & 0,511 & $1,46(0,48-4,48)$ \\
& Aß42 & 1,125 & 0,045 & $3,08(1,02-9,26)$ \\
Langkah 2 & Konstanta & $-1,376$ & 0,025 & 0,25 \\
& Tama Sakit & 1,310 & 0,021 & $3,75(1,22-11,29)$ \\
& Aingkat Pendidikan & 0,328 & 0,56 & $1,39(0,46-4,19)$ \\
& Konstanta & 1,170 & 0,035 & $3,22(1,08-9,58)$ \\
Langkah 3 & Lama Sakit & $-1,249$ & 0,028 & 0,287 \\
& Aß42 & 1,374 & 0,014 & $3,95(1,32-11,79)$ \\
& Konstanta & 1,193 & 0,031 & $3,29(1,114-9,76)$ \\
& 1,092 & 0,027 & 0,336 \\
\hline
\end{tabular}

RO: rasio Odds; IK: interval kepercayaan; $A \beta$ : amiloid beta. 
tingginya tingkat pendidikan berbanding lurus dengan besarnya cadangan kognitif, yang terlihat dari kemampuan mengerjakan tugas-tugas pada tes neuropsikologi secara efisien. ${ }^{11}$

Pada penelitian ini tidak terdapat hubungan yang bermakna antara kadar A $\beta 40$ dengan kejadian gangguan fungsi kognitif, namun terdapat kecenderungan peninggian kadar A $\beta 40$ pada kelompok dengan gangguan kognitif. Tingginya kadar A $\beta 40$ pada kelompok dengan gangguan kognitif kemungkinan disebabkan oleh berkurangnya pembersihan $A \beta$ sistemik oleh hati dan ginjal (terutama hati). Dari studi pada binatang diketahui bahwa pembersihan sistemik $A \beta$ dipengaruhi oleh usia, pembersihan pada usia tua lebih lambat dibanding usia muda. ${ }^{8,12}$

Terdapat hubungan yang bermakna antara rendahnya kadar A $\beta 42$ plasma dengan terjadinya gangguan kognitif pada pasien DM. Rendahnya kadar A $\beta 42$ di plasma bisa terjadi karena berkurangnya pembersihan $\mathrm{A} \beta 42$ dari otak ke perifer, dan atau bisa juga karena transportasinya dari sistemik ke otak meningkat, karena meningkatnya kadar receptor advancef glycosilation endproduct, yaitu reseptor yang membantu masuknya $A \beta 42$ dari sistemik ke otak, sehingga kadar A $\beta 42$ di jaringan otak akan meningkat. ${ }^{5}$ Puzzo menemukan bahwa kosentrasi rendah dari A $\beta 42$ monomer dan oligomer menyebabkan pemanjangan longterm potentiation (LTP) dan kosentrasi tinggi dari nanomolar $(200 \mathrm{nM})$ menyebabkan menurunnya potensiasi pada hipokampus. ${ }^{13}$

Pada dasarnya gangguan fungsi kognitif pada demensia adalah gangguan pada sinaps oleh $A \beta$. Secara fisiologis, kosentrasi rendah dari $A \beta$ diperlukan untuk mengatur dan mempertahankan plastisitas dari sinaps dan untuk meningkatkan fungsi kognitif, namun penumpukan $A \beta$ dalam kosentrasi yang lebih tinggi, ditambah lagi dengan pengaruh pertambahan usia akan menyebabkan kerusakan pada fungsi pengaturan ini dengan konsekuensi disfungsi dan kerusakan pada sinaps, seperti yang terlihat pada penderita demensia. ${ }^{14-16}$

Penelitian ini memiliki beberapa keterbatasan, diantaranya adalah variasi usia dan rentang lama sakit yang yang cukup besar, sehingga kondisi ini mungkin dapat memengaruhi hasil.

\section{KESIMPULAN}

Terdapat hubungan yang bermakna antara lamanya menderita DM dan rendahnya kadar A 342 dengan terjadinya gangguan kognitif pada penderita DM tipe 2.

\section{DAFTAR PUSTAKA}

1. Ninomiya T. Diabetes mellitus and dementia. Curr Diab Rep. 2014;14(5):487.

2. Munshi MN. Cognitive dysfunction in older adults with diabetes: what a clinician needs to know. Diabetes Care. 2017;40(4):461-7.

3. Cheng DJ, Noble J, Tang MX, Schupf N, Mayeux $\mathrm{R}$, Luchsinger JA. Type 2 diabetes and late-onset Alzheimer's disease. Dement Geriatr Cogn Disord. 2011;31(6):424-30.

4. World Health Organization. World health reportshaping the future. Geneva: WHO; 2003.

5. Deane R, Bell RD, Sagare A, and Zlokovic BV. Clearance of amyloid- $\beta$ peptide across the bloodbrain barrier: implication for therapies in Alzheimer's disease. CNS Neurol Disord Drug Targets. 2009;8(1):16-30.

6. Kodl CT, Seaquist ER. Cognition and diabetes mellitus. Endocrine Reviews. 2008;29(4):494-511.

7. Cárdenas-Aguayo MD, Silva-Lucero MD, CortesOrtiz M, Jiménez-Ramos B, Gómez-Virgilio L, Ramírez-Rodríguez G, dkk. Physiological role of amyloid beta in neural cells: the cellular trophic activity. InNeurochemistry; 2014.

8. Kalaria RN. Comparison between Alzheimer's disease and vascular dementia: implications for treatment. Neurol Res. 2003;25(6):661-4.

9. Wang J, Gu BJ, Master CL, Wang YJ. Systemic view of Alzheimer disease-insights from amyloid $\beta$ metabolism beyond the brain. Nature Rev Neurol. 2017;13(10):612-23.

10. Rawlings AM, Sharrett AR, Schneider AL, Coresh J, Albert M, Couper D, dkk. Diabetes in midlife and cognitive change over 20 years: a cohort study. Ann Intern Med. 2014;161(11):785-93.

11. Lenehan ME, Summers MJ, Saunders NL, Summers JJ, Vicker JC. Relationship between education and age-related cognitive decline: a review of a recent research. Psychogeriatrics. 2014;2014:1-9.

12. Krabbe G, Halle A, Matyash V, Rinnenthal JL, Eom GD, Bernhardt U, dkk. Functional impairment of microglia coincides with ßamyloid deposition in mice with Alzheimer-like pathology. PLoS ONE. 2013;8(4):e60921.

13. Puzzo D, Privitera L, Leznik E, Fà M, Staniszewski 
A, Palmeri A, dkk. Picomolar amyloid-beta positively modulates synaptic plasticity and memory in hippocampus. J Neurosci. 2008;28(53):14537-45.

14. Mackic JB, Bading J, Ghiso J, Walker L, Wisniewski T, Frangione B, dkk. Circulating amyloid-beta peptide crosses the blood brain barrier in aged monkey and contributes to Alzheimer's disease lesions. Vascul Pharmacol. 2002;38(6):303-13.
15. Bishop GM, Robinson SR. Physiological roles of amyloid- $\beta$ and implications for its removal in alzheimer's disease. Drugs Aging. 2004;21(10):621-30.

16. Parihar MS, Brewewr GJ. Amyloid beta as a modulator of synaptic plasticity. J Alzheimers Dis. 2010;22(3):741-63. 